\section{JURNAL EKONOMI EFEKTIF}

ISSN : $2622-8882$, E-ISSN : 2622-9935

Jurnal Ekonomi Efektif, Vol. 3, No. 3, April 2021

@Prodi Manajemen Fakultas Ekonomi Universitas

Pamulang

\title{
PENGARUH PELATIHAN TERHADAP PRESTASI KERJA KARYAWAN PADA PT. BANK HSBC CABANG PONDOK INDAH
}

\author{
Desi Prasetiyani \\ Universitas Pamulang, Tangerang Selatan, Banten, Indonesia \\ dosen02496@unpam.ac.id
}

Manuskrip: Feb-2021 Ditinjau: Mar-2021; Diterima: Mar-2021; Online: Apr-2021; Diterbitkan: Apr-2021

\begin{abstract}
ABSTRAK
Penelitian ini bertujuan untuk mengetahui pengaruh pelatihan terhadap prestasi kerja karyawan pada PT. Bank HSBC Cabang Pondok Indah. Metode yang digunakan adalah explanatory research dengan sampel sebanyak 83 responden. Teknik analisis menggunakan analisis statistik dengan pengujian regresi, korelasi, determinasi dan uji hipotesis. Hasil penelitian ini variabel pelatihan diperoleh nilai rata-rata skor sebesar 3,417 dengan kriteria baik. Variabel prestasi kerja karyawan diperoleh nilai rata-rata skor sebesar 3,789 dengan kriteria baik. Pelatihan berpengaruh positif dan signifikan terhadap prestasi kerja karyawan dengan nilai persamaan regresi $\mathrm{Y}=12,054+0,766 \mathrm{X}$, dan nilai koefisien korelasi 0,746 atau memiliki tingkat hubungan yang kuat dengan nilai determinasi $55,7 \%$. Uji hipotesis diperoleh signifikansi $0,000<0,05$.
\end{abstract}

Kata Kunci: Pelatihan, Prestasi Kerja Karyawan.

\begin{abstract}
This study aims to determine the effect of training on employee performance at PT. HSBC Bank Pondok Indah Branch. The method used is explanatory research with a sample of 83 respondents. The analysis technique uses statistical analysis with regression testing, correlation, determination and hypothesis testing. The results of this study of the training variable obtained an average score of 3,417 with good criteria. Employee performance variable obtained an average score of 3.789 with good criteria. Training has a positive and significant effect on employee work performance with the regression equation $Y=12.054+$ $0.766 X$, and the correlation coefficient value of 0.746 or has a strong level of relationship with a determination value of 55.7\%. Hypothesis testing obtained a significance of $0.000<0.05$.
\end{abstract}

Keywords: Training, Employee Performance. 


\section{PENDAHULUAN}

\section{A. Latar Belakang Masalah}

Dalam menghadapi era globalisasi, banyak tantangan yang harus dihadapi oleh perusahaan dalam rangka meningkatkan persaingan. Baik dalam perusahaan kecil, menengah maupun besar di Indonesia, untuk dapat bertahan dan memenangkan persaingan dituntut memiliki keunggulan bersaing. Salah satu faktor yang dapat dijadikan pegangan perusahaan dalam menciptakan keunggulan bersaing adalah dengan keunggulan produk dan sumber daya manusia yang berkualitas yang akan memberikan kontribusi bagi penciptaan keunggulan bersaing pada era globalisasi.

Untuk mempersiapkan sumber daya manusia tidak hanya dilihat dari segi kuantitasnya saja, sebab tersediannya sumber daya manusia yang cukup banyak belum tentu merupakan jaminan bahwa hasil yang dicapai akan efisien dan efektif. Sebagai langkah awal untuk mendapatkan sumber daya manusia yang berkualitas adalah dimulai dengan menarik dan memiliki tenaga yang sesuai dengan standar personalia perusahaan. Standar ini merupakan persyaratan minimal yang harus dipenuhi agar seorang karyawan bias mengerjakan pekerjaan-pekerjaannya dengan baik, disamping itu langkah selanjutnya untuk terus meningkatkan sumber daya manusia yang terampil dan berkemampuan tinggi adalah dengan memberikan Pendidikan dan pelatihan terhadap setiap pelaku organisasi secara berkeseimbangan dengan metode yang sistematis.

Pelatihan harus tetap dilaksanakan karena pelatihan tersebut mempunyai manfaat yang besar bagi perusahaan atau pegawai perusahaan. Manfaat bagi perusahaan antara lain adalah perusahaan mempunyai tenaga kerja yang siap melaksanakan pekerjaannya sehingga dengan adanya tenaga kerja yang demikian perusahaan dapat mencapai tujuannya dengan lebih mudah.

Dengan dilaksanakan pelatihan diharapkan pegawai akan semakin mampu memahami dan melaksanakan fungsinya dalam organisasi. Disamping itu juga diharapkan pula adanya perbaikan atau pengembangan sikap, tingkah laku, pengetahuan serta keterampilan dari para pelaku organisasi agar tercapainya tujuan perusahaan.

Pada posisi lain dengan adanya peningkatan mutu pegawai melalui pelatihan, diharapkan dapat memberikan pengaruh terhadap pribadi setiap peserta pelatihan, sehingga ia dapat melakukan pekerjaan-pekerjaan yang lebih beragam, sejalan dengan tujuan perusahaan secara lebih baik dan profesional. Hal ini berarti adanya peningkatan kualifikasi pegawai tersebut, dan lebih jauh lagi berarti suatu langkah maju untuk mendapatkan posisi dan tanggung jawab yang lebih besar pada perusahaan tersebut.

Bank HSBC diberi nama sesuai dengan tempat awal pendiriannya, Hongkong and Shanghai Banking Corporation Limited, yang didirikan pada tahun 1865 untuk membiayai perdagangan yang sedang bertumbuh antara Eropa, India dan Tiongkok.

Pencetus gagasan dibalik pendirian bank ini adalah Thomas Sutherland, seorang Scotlandia yang saat itu bekerja untuk Peninsular and Oriental Steam Navigation Company. Dia menyadari adanya kebutuhan yang cukup besar akan fasilitas perbankan lokal di Hong Kong dan pesisir Tiongkok, dan dia membantu mendirikan bank tersebut pertama kalinya di Hong Kong pada bulan Maret tahun 1865 dan di Shanghai satu bulan kemudian.

Bank ini mulai membuka kantor-kantor cabang untuk memperluas layanan yang dapat diberikan kepada para nasabah. Sejak awal, pembiayaan perdagangan merupakan bisnis unggulan bank ini baik lokal maupun internasional, kekuatan yang telah diakui sepanjang sejarahnya. Pada akhir abad ke 19, bank ini menjadi lembaga keuangan yang paling terkemuka di Asia. 
Pada abad ke 20 bank menghadapi tantangan dan perubahan, yang timbul karena konflik internasional hingga Depresi Ekonomi Besar (Great Depression) pada tahun 1930-an. Menjelang akhir abad tersebut, melalui pertumbuhan, akuisisi dan diversifikasi, Bank HSBC telah berubah dari bank regional yang penting menjadi salah satu lembaga keuangan terkemuka di dunia.

Bank HSBC sendiri telah beroperasi di Indonesia sejak tahun 1884. Dulunya bank ini bernama The Hongkong and Shanghai Banking Corporation Limited dan membuka cabang di Batavia (nama sebelum Jakarta) untuk melayani perdagangan gula yang pada masa itu sangat penting di kawasan Hindia. Pada tahun, 1896 Bank HSBC akhirnya membuka kantor cabang di Surabaya, kota pelabuhan ke dua terpenting di Indonesia.

Bank HSBC terus berkembang di Indonesia hingga terjadinya Perang Dunia Kedua, dimana bank tersebut terpaksa menghentikan kegiatannya di Indonesia. Bank HSBC kemudian masuk kembali ke Indonesia dan mendapatkan ijin perbankan baru pada tahun 1968.Sampai saat ini, Bank HSBC menjadi salah satu bank asing terbesar yang beroperasi di Indonesia saat ini.

Untuk menghadapi persaingan pasar industri perbankan, perusahaan memandang pentingnya pelatihan dilakukan untuk membekali karyawannya dalam rangka memperlancar pekerjaan. Menurut Kaswan (2011:2) Pelatihan adalah proses peningkatan pengetahuan dan keterampilan karyawan. Pelatihan mungkin juga meliputi pengubahan sikap sehingga karyawan dapat melakukan pekerjaannya lebih efektif.

Menurut Hasibuan (2005:87) Prestasi kerja adalah suatu hasil kerja yang dicapai seseorang dalam melaksanakan tugas-tugas yang dibebankan kepadanya yang didasarkan atas kecakapan, pengalaman, dan kesungguhan. PT. Bank HSBC Indonesia, menyadari bahwa manajemen sumber daya manusia merupakan pactor yang sangat penting dalam kegiatan perusahaan dan perusahaan menyadari betul bahwa mereka membutuhkan karyawan-karyawan yang berkualitas untuk mendukung kegiatan operasional perusahaan. Salah satu perusahaan mendapatkan karyawan-karyawan yang berkualitas yaitu dengan melakukan pelatihan terhadap karyawan tersebut sehingga dapat meningkatkan kemampuan dari mereka. Untuk itu meskipun saat ini perusahaan dalam keadaan menurun tetapi perusahaan tetap menjalankan pelatihan bagi karyawan karena menurut perusahaan kegiatan tersebut sangat penting untuk dilakukan. Tetapi pelatihan dapat membantu karyawan untuk meningkatkan keterampila, pengetahuan karyawan yang akhirnya dapat menciptakan prestasi kerja karyawan, konsep prestasi kerja merupakan suatu hasil kerja yang dicapai seseorang dalam melaksanakan tugas-tugasnya yang dibebankan kepadanya yang berdasarkan atas kecakapan pengalaman dan kesungguhan serta waktu, berikut disajikan hasil operasionalalisasi variable pada departemen Credit Operasional PT. Bank HSBC Indonesia Cabang Pondok Indah.

Didalam perusahaan seseorang karyawan dianggap berprestasi apa bila ia mampu mencapai target-target yang ditetapkan, dalam kurun waktu tertentu dan dengan sistematika kerja yang jelas. Sebaliknya bagi mereka yang tidak mampu bekerja dengan sistematika yang jelas, maka ia tidak dianggap berprestasi. DiDepartemen Credit Operasional PT. Bank HSBC Indonesia Cabang Pondok Indah masih banyak karyawan yang kerjanya tidak mencapai target dan tidak tepat waktu, dikarenakan menyepelekan pekerjaan yang ada, yang dianggap pekerjaan itu mudah dikerjakan dikarenakan karyawan menggangap pekerjaan itu sudah terbiasa dikerjakan atau karyawan menggap pekerjaan itu sudah kebiasaan sehari-hari yang dikerjakan.

Berdasarkan uraian di atas maka penulis tertarik untuk melakukan penelitian dengan judul Pengaruh Pelatihan Terhadap Prestasi Kerja Karyawan Pada PT. Bank HSBC Indonesia Cabang Pondok Indah. 


\section{B. Rumusan Masalah}

1. Bagaimana pelatihan pada PT. Bank HSBC Cabang Pondok Indah ?.

2. Bagaimana prestasi kerja karyawan pada PT. Bank HSBC Cabang Pondok Indah ?.

3. Adakah pengaruh antara pelatihan terhadap prestasi kerja karyawan pada PT. Bank HSBC Cabang Pondok Indah ?.

\section{Tujuan Penelitian}

1. Untuk mengetahui kondisi pelatihan pada PT. Bank HSBC Cabang Pondok Indah.

2. Untuk mengetahui kondisi prestasi kerja karyawan pada PT. Bank HSBC Cabang Pondok Indah.

3. Untuk mengetahui pengaruh antara pelatihan terhadap prestasi kerja karyawan pada PT. Bank HSBC Cabang Pondok Indah.

\section{METODE PENELITIAN}

\section{Populasi}

Populasi dalam penelitian ini berjumlah 83 responden PT. Bank HSBC Cabang Pondok Indah

\section{Sampel}

Teknik pengambilan sampling dalam penelitian ini adalah sampel jenuh, dimana semua anggota populasi dijadikan sebagai sampel. Dengan demikian sampel dalam penelitian ini sampel yang digunakan berjumlah 83 responden.

\section{Jenis Penelitian}

Jenis penelitian yang dipakai adalah asosiatif, dimana tujuannya adalah untuk mengetahui atau mencari keterhubungan antara variabel independen terhadap variabel dependennya

\section{Metode Analisis Data}

Dalam menganalisis data digunakan uji validitas, uji reliabilitas, analisis regresi linier sederhana, analisis koefisien korelasi, analisis koefisien determinasi dan pengujian hipotesis.

\section{HASIL PENELITIAN DAN PEMBAHASAN}

\section{Analisis Deskriptif}

Pada pengujian ini digunakan untuk mengetahui skor minimum dan maksimum skor tertinggi, ratting score dan standar deviasi dari masing-masing variabel. Adapun hasilnya sebagai berikut:

Tabel 1. Hasil Analisis Descriptive Statistics

Descriptive Statistics

\begin{tabular}{lr|r|r|r|r} 
& \multicolumn{2}{c}{ Descriptive Statistics } & & \\
& N & Minimum & Maximum & Mean & Std. Deviation \\
\hline Pelatihan (X) & 80 & 28 & 44 & 34.00 & 4.016 \\
\hline Prestasi kerja Karyawan (Y) & 80 & 29 & 49 & 38.11 & 4.183 \\
\hline Valid N (listwise) & 80 & & & & \\
\hline
\end{tabular}

Pelatihan diperoleh varians minimum sebesar 28 dan varians maximum 46 dengan ratting score sebesar 3,417 dengan standar deviasi 3,917. Skor ini termasuk pada rentang sakala 3,40 - 4,19 dengan kriteria baik atau setuju.

Prestasi kerja karyawan diperoleh varians minimum sebesar 29 dan varians maximum 49 dengan ratting score sebesar 3,789 dengan standar deviasi 4,021. Skor ini termasuk pada rentang sakala 3,40 - 4,19 dengan kriteria baik atau setuju. 


\section{Analisis Verifikatif.}

Pada analisis ini dimaksudkan untuk mengetahui pengaruh variabel independen terhadap variabel dependen. Adapun hasil pengujian sebagai berikut:

\section{a. Analisis Regresi Linier Sederhana}

Uji regresi ini dimaksudkan untuk mengetahui perubahan variabel dependen jika variabel independen mengalami perubahan. Adapun hasil pengujiannya sebagai berikut:

Tabel 2. Hasil Pengujian Regresi Linier Sederhana

\section{Coefficients $^{\mathrm{a}}$}

\begin{tabular}{|c|c|c|c|c|c|}
\hline \multirow[b]{2}{*}{ Model } & \multicolumn{2}{|c|}{$\begin{array}{c}\text { Unstandardized } \\
\text { Coefficients }\end{array}$} & \multirow{2}{*}{$\begin{array}{c}\text { Standardized } \\
\text { Coefficients } \\
\text { Beta }\end{array}$} & \multirow[t]{2}{*}{$\mathrm{t}$} & \multirow[t]{2}{*}{ Sig. } \\
\hline & $\mathrm{B}$ & Std. Error & & & \\
\hline 1 (Constant) & 12.054 & 2.579 & & 4.673 & .000 \\
\hline Pelatihan (X) & .766 & .076 & .746 & 10.083 & .000 \\
\hline
\end{tabular}

Berdasarkan hasil pengujian pada tabel di atas, diperoleh persamaan regresi $\mathrm{Y}$ $=12,054+0,766 \mathrm{X}$. Dari persamaan tersebut dijelaskan sebagai berikut:

1) Konstanta sebesar 12,054 diartikan jika pelatihan tidak ada, maka telah terdapat nilai prestasi kerja karyawan sebesar 12,054 point.

2) Koefisien regresi pelatihan sebesar 0,766 , angka ini positif artinya setiap ada peningkatan pelatihan sebesar 0,766 point maka prestasi kerja karyawan juga akan mengalami peningkatan sebesar 0,766 point.

\section{b. Analisis Koefisien Korelasi}

Analisis koefisien korelasi dimaksudkan untuk mengetahui tingkat kekuatan hubungan dari variabel independen terhadap variabel dependen. Adapun hasil pengujian sebagai berikut:

Tabel 3. Hasil Pengujian Koefisien Korelasi Pelatihan Terhadap Prestasi kerja

Karyawan

Correlationsb

\begin{tabular}{llr|r} 
& & Motivasi (X1) & Kinerja Karyawan (Y) \\
\hline Pelatihan (X) & Pearson Correlation & 1 & $.767^{* *}$ \\
\cline { 2 - 4 } & Sig. (2-tailed) & & .000 \\
\hline Prestasi kerja & Pearson Correlation & $.767^{* *}$ & 1 \\
\cline { 2 - 4 } Karyawan (Y) & Sig. (2-tailed) & .000 & \\
\hline
\end{tabular}

Berdasarkan hasil pengujian diperoleh nilai korelasi sebesar 0,746 artinya pelatihan memiliki hubungan yang kuat terhadap prestasi kerja karyawan.

\section{c. Analisis Koefisien Determinasi}

Analisis koefisien determinasi dimaksudkan untuk mengetahui besarnya persentase pengaruh dari variabel independen terhadap variabel dependen. Adapun hasil pengujian sebagai berikut:

Tabel 4. Hasil Pengujian Koefisien Determinasi Pelatihan Terhadap Prestasi kerja Karyawan.

\section{Model Summary}

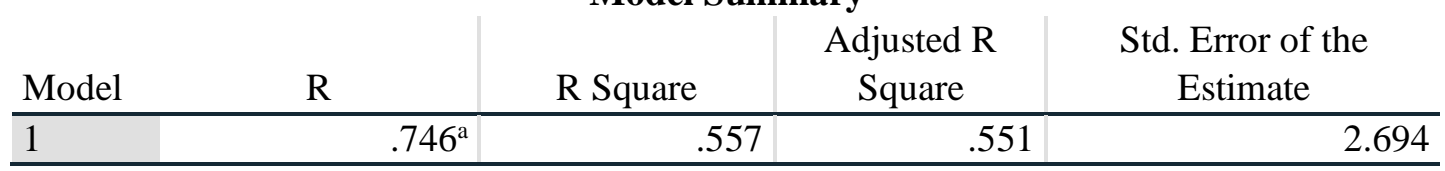

Berdasarkan hasil pengujian diperoleh nilai determinasi sebesar 0,557 artinya 
pelatihan memiliki kontribusi pengaruh sebesar 55,7\% terhadap prestasi kerja karyawan, sedangkan sisanya sebesar $44,3 \%$ dipengaruhi oleh faktor lain yang tidak dilakukan penelitian.

\section{d. Uji Hipotesis}

Pengujian hipotesis dengan uji t digunakan untuk mengetahui hipotesis mana yang diterima. Rumusan hipotesis: Terdapat pengaruh yang signifikan antara pelatihan terhadap prestasi kerja karyawan.

Tabel 5. Hasil Uji Hipotesis Pelatihan Terhadap Prestasi kerja Karyawan.

\section{Coefficients $^{\mathbf{a}}$}

\begin{tabular}{|c|c|c|c|c|c|}
\hline \multirow[b]{2}{*}{ Model } & \multicolumn{2}{|c|}{ Unstandardized Coefficients } & \multirow{2}{*}{$\begin{array}{c}\text { Standardized } \\
\text { Coefficients } \\
\text { Beta }\end{array}$} & \multirow[t]{2}{*}{$\mathrm{t}$} & \multirow[t]{2}{*}{ Sig. } \\
\hline & B & Std. Error & & & \\
\hline 1 (Constant) & 12.054 & 2.579 & & 4.673 & .000 \\
\hline Pelatihan $(\mathrm{X})$ & .766 & .076 & .746 & $\begin{array}{r}10.08 \\
3\end{array}$ & .000 \\
\hline
\end{tabular}

Berdasarkan hasil pengujian pada tabel di atas, diperoleh nilai t hitung $>\mathrm{t}$ tabel atau $(10,083>1,990)$, dengan demikian hipotesis yang diajukan bahwa terdapat pengaruh yang signifikan atara pelatihan terhadap prestasi kerja karyawan diterima.

\section{PEMBAHASAN HASIL PENELITIAN}

\section{Kondisi Jawaban Responden Variabel Pelatihan}

Berdasarkan jawaban responden, variabel pelatihan diperoleh ratting score sebesar 3,417 berada di rentang skala 3,40-4,19 dengan kriteria baik atau setuju.

\section{Kondisi Jawaban Responden Variabel Prestasi kerja Karyawan}

Berdasarkan jawaban responden, variabel prestasi kerja karyawan diperoleh ratting score sebesar 3,789 berada di rentang skala 3,40 - 4,19 dengan kriteria baik atau setuju.

\section{Pengaruh Pelatihan Terhadap Prestasi kerja Karyawan}

Pelatihan berpengaruh signifikan terhadap prestasi kerja karyawan dengan persamaan regresi $\mathrm{Y}=12,054+0,766 \mathrm{X}$, nilai korelasi sebesar 0,746 atau memiliki hubungan yang kuat dengan kontribusi pengaruh sebesar 55,7\%. Pengujian hipotesis diperoleh nilai t hitung $>\mathrm{t}$ tabel atau $(10,083>1,990)$. Dengan demikian hipotesis yang diajukan bahwa terdapat berpengaruh signifikan antara pelatihan terhadap prestasi kerja karyawan diterima.

\section{PENUTUP}

\section{Kesimpulan}

a. Variabel pelatihan diperoleh ratting score sebesar 3,417 berada di rentang skala 3,40 $-4,19$ dengan kriteria baik atau setuju.

b. Variabel prestasi kerja karyawan diperoleh ratting score sebesar 3,789 berada di rentang skala 3,40-4,19 dengan kriteria baik atau setuju.

c. Pelatihan berpengaruh signifikan terhadap prestasi kerja karyawan dengan persamaan regresi $\mathrm{Y}=12,054+0,766 \mathrm{X}$, nilai korelasi sebesar 0,746 atau kuat dan kontribusi pengaruh sebesar $55,7 \%$ sedangkan sisanya sebesar $44,3 \%$ dipengaruhi faktor lain. Uji hipotesis diperoleh nilai $\mathrm{t}$ hitung $>\mathrm{t}$ tabel atau $(10,083>1,990)$. 


\section{Saran}

a. Materi yang disampaikan dalam pelatihan seharusnya sesuai dengan tujuan yang ingin dicapai oleh perusahaan dan materi yang disampaikan mampu menambah pengetahuan peserta pelatihan.

b. Seharusnya karyawan mampu bekerja sama dengan semua karyawan, dan memberikan bantuan jika rekan kerja mengalami permasalahan dalam bekerja, kerja sama dapat memberikan kemudahan dan mempercepat pekerjaan.

\section{DAFTAR PUSTAKA}

Abdullah, M (2014) Manajemen dan Evaluasi Prestasi kerja Karyawan, Yogyakarta: Penerbit Aswaja Pressindo.

Affandi, A, et al (2020). Manajemen SDM Strategik. Serang. Bintang Visitama

Affandi, A., Sarwani, A. S., Erlangga, H., Siagian, A. O., Purwanto, A., Effendy, A. A., ... \& Wahyitno, C. D. M. (2020). Optimization of MSMEs Empowerment in Facing Competition in the Global Market during the COVID-19 Pandemic Time. Systematic Reviews in Pharmacy, 11(11), 1506-1515.

Algifari. (2015). “Analisis Regresi untuk Bisnis dan Ekonomi”. Yogyakarta: BPFE..

AM, E. N., Affandi, A., Udobong, A., \& Sarwani, S. (2020). Implementation of Human Resource Management in the Adaptation Period for New Habits. International Journal of Educational Administration, Management, and Leadership, 19-26.

Arikunto, Suharsimi (2014). "Prosedur Penelitian Suatu Pendekatan Praktek". Jakarta: Rineka Cipta.

Bangun, Wilson. 2012. "Manajemen Sumber Daya Manusia”. Jakarta: Erlangga

Bejo Siswanto (2013) Manajemen Tenaga Kerja Rancangan dalam Pendayagunaan dan Pengembangan Unsur Tenaga Kerja”, Bandung: Sinar Baru.

Dessler, G. (2006.) Manajemen Sumber Daya Manusia (Jilid II). Jakarta: Indeks.

Edi Sutrisno (2016). Manajemen Sumber Daya Manusia. Jakarta: Prenadamedia Group.

Flippo, Edwin B. 2002. Personel Management (Manajemen Personalia), Edisi VII Jilid II, Terjemahan Alponso S, Erlangga, Jakarta.

George Terry R \& Rue, Leslie W. Rue (2016) Dasar-Dasar Manajemen, Jakarta Bumi Aksara.

Gerry Dessler (2016) Human Resources Management, Prenticehall, London: International Inc.

Handoko (2016) Manajemen Personalia dan Sumberdaya Manusia. Yogyakarta: BPFE.

Hasibuan, Malayu S.P. (2016). Manajemen Sumber Daya Manusia. Edisi Revisi. Jakarta: PT Bumi Aksara.

Imam Ghozali (2017). “Aplikasi Analisis Multivariate Dengan Program SPSS”. Edisi Kelima. Semarang: Badan Penerbit Undip.

Istijanto (2014) "Riset Sumber Daya Manusia". Jakarta: PT. Gramedia Pustaka

Jasmani, J., \& Sunarsi, D. (2020). The Influence of Product Mix, Promotion Mix and Brand Image on Consumer Purchasing Decisions of Sari Roti Products in South Tangerang. PINISI Discretion Review, 1(1), 165-174.

Kaso, N., Mariani, M., Ilham, D., Firman, F., Aswar, N., \& Iksan, M. (2021). The Principal's Leadership: How to Improve the Quality of Teaching and Learning Process in State Junior High School of Luwu. Jurnal Ad'ministrare, 8(1), 49-58. https://doi.org/10.26858/ja.v8i1.19126

Kaswan. 2011. Pelatihan dan Pengembangan untuk meningkatkan Kinerja Sumber Daya Manusia, Bandung. ALFABETA.

Kristianti, L. S., Affandi, A., Nurjaya, N., Sunarsi, D., \& Rozi, A. (2021). Pengaruh 
Motivasi Dan Disiplin Kerja Terhadap Kinerja Pegawai Pada Dinas Pariwisata

Purwakarta. Jurnal Ilmah PERKUSI, 1(1), 101-109.

Luthans Fred (2014) Organizational Behavior, Ney York: McGraw-Hill, New York.

Mangkunegara, Ahmad Prabu, 2010, Manajemen Sumber Daya Manusia Perusahaan. Bandung, penerbit Remaja Rosdakarya.

Mangkunegara, Prabu Anwar. (2016). Evaluasi Prestasi kerja SDM. Cetakan ke tujuh, PT Refika Aditama: Bandung.

Mangkunegara. A.A.Anwar Prabu, 2011. Manajemen Sumber Daya Manusia

Mathis, Robert L. dan John H. Jackson. (2006). Manajemen Sumber Daya Manusia edisi 10. Thomson South-Western.

Mathis, Robert L. dan John H. Jackson. (2012). Manajemen Sumber Daya Manusia, Edisi Pertama Salemba Empat, Jakarta.

Mulyadi, M. (2018). Pengaruh Pelatihan Dan Motivasi Terhadap Kinerja Karyawan Pada PT. Permata Lestari. JENIUS (Jurnal Ilmiah Manajemen Sumber Daya Manusia), 2(1).

Muslimat, A., Muhsin, H., Wahid, H. A., Yulistiana, I., Sunarsi, D., Dewi, K., ... \& Ilham, D. (2021). Develop Technology Based Multimedia For Indonesian Teachers. Journal of Contemporary Issues in Business and Government, 27(1), 1871-1882.

Nurjaya, N., Sobarna, A., Affandi, A., Erlangga, H., \& Sarwani, S. (2020). Edupreneurship management in shaping the nation's character. Jurnal Konseling dan Pendidikan, 8(3), 198-206.

Permatasari, R. J. (2018). Analisis Pengaruh Pendidikan Dan Pelatihan, Motivasi Dan Kompensasi Terhadap Kinerja Karyawan (Pada Citibank Pondok Indah Jakarta Selatan). JENIUS (Jurnal Ilmiah Manajemen Sumber Daya Manusia), 1(3).

Rifuddin, B., Ilham, D., \& K, N. (2020). Academic Services in Islamic Education Management Study Program: The Actualization of the Basic Values of the State Civil Apparatus at IAIN Palopo. International Journal of Asian Education, 1(2), 8194. https://doi.org/10.46966/ijae.v1i2.34

Robbins, Stephen P., dan Mary Coulter. 2010. Manajemen. Jilid 1. Jakarta :

Santoso, Singgih (2015). "Menguasai Statistik Multivariat". Jakarta: PT Elex Media Komputindo.

Sedarmayanti (2016) Manajemen Sumber Daya Manusia, Reformasi Birokrasi dan Manajemen Karyawan Negeri Sipil, Cetakan Kelima, Bandung: PT Refika Aditama.

Steers, Richard. (2005). Efektivitas Organisasi Terjemahan Magdalena. Jakarta: Erlangga. Sudjana (2014) "Metode Statistika", Bandung: Tarsido.

Sugiono. (2010). Metode Penelitian Kuantitatif Kuantitatif \& RND. Bandung Alfabeta.

Sugiono. (2011). Metode Penelitian Pendidikan. Bandung : Alfabeta.

Sugiyono (2017), "Metode Penelitian Administrasi : dilengkapi dengan Metode R \& D". Bandung: Alfabeta.

Suhartanto (2014). "Metode Riset Pemasaran". Bandung: Alfabeta

Sukmadinata, Nana Syaodih, (2011). Metode Penelitian Pendidikan. Bandung: PT.Remaja Rosdakarya.

Sutrisno, S. (2018). Pengaruh Pelatihan Pelayanan Prima Dan Disiplin Kerja Terhadap Kinerja Karyawan Pada PT. Sumber Sarana. JENIUS (Jurnal Ilmiah Manajemen Sumber Daya Manusia), 2(1).

Veithzal Rivai (2015) Manajemen Sumber Daya Manusia Untuk Perusahaan, Jakarta: Raja Grafindo Persada.

Wibowo (2015) Manajemen Prestasi kerja, Jakarta: PT. Raja Grafindo Persada 